\title{
Identifying Antioxidant and Antimicrobial Activities of the Phenolic Extracts and Mineral Contents of Virgin Olive Oils (Olea europaea L. cv. Edincik Su) from Different Regions in Turkey
}

\author{
Ayhan Dağdelen \\ Department of Food Engineering, Faculty of Engineering and Architecture, Balikesir University, 10145 Balikesir, Turkey \\ Correspondence should be addressed to Ayhan Dağdelen; dagdelen@balikesir.edu.tr
}

Received 8 February 2016; Revised 1 April 2016; Accepted 12 April 2016

Academic Editor: Lorenzo Cerretani

Copyright (C) 2016 Ayhan Dağdelen. This is an open access article distributed under the Creative Commons Attribution License, which permits unrestricted use, distribution, and reproduction in any medium, provided the original work is properly cited.

\begin{abstract}
The objective of this study was to identify the antioxidant and antimicrobial activities of the phenolic extracts and mineral contents of virgin olive oils (Olea europaea L. cv. Edincik Su) obtained from three different locations, Edincik, Gomec, and Izmir, in Turkey. Antioxidant activity was analysed spectrometrically, antimicrobial effect was evaluated by disc diffusion method, and mineral contents were determined by using Inductively Coupled Plasma-Optical Emission Spectrometry (ICP-OES). Total phenolic contents and free radical scavenging activities of Edincik Su olive cultivar were found between 159.99 and $189.64 \mathrm{mg}$ gallic acid equivalent $/ \mathrm{kg}$ and 21.76 and $31.79 \%$ inhibition of $\mathrm{DPPH}^{\circ}$ radical values, respectively. Phenolic composition was also varied according to location and hydroxytyrosol and tyrosol were determined as major phenolic compounds. Fourteen pathogenic bacteria and two fungal strains were used to determine the antimicrobial activity. Phenolic extracts showed antimicrobial effect against a wide range of microorganisms and the descending rank of the antimicrobial activities was Gomec, Izmir, and Edincik samples. The highest antimicrobial activities were determined against Clostridium perfringens ATCC 13124 and Campylobacter jejuni ATCC 33291 in all samples. Sixteen elements were used as standards (eleven of them were heavy metals) to identify mineral contents. Fe, Mg, Sn, K, and $\mathrm{Ca}$ were determined in Gomec samples and $\mathrm{Mg}$ and $\mathrm{K}$ were detected in Edincik samples while no mineral content was detected in Izmir sample.
\end{abstract}

\section{Introduction}

Virgin olive oil (VOO) which is obtained from olive fruit (Olea europaea L.) by mechanical processing method is well known and accepted as a main component of the Mediterranean diet all over the world with its unique taste and flavor, high contents of natural antioxidants, and balanced ratio of saturated and unsaturated fatty acids including high amounts of oleic acid [1].

Olive oil prevents the formation of various cancer types as intestine, prostate, and breast, neurological disorders, and cardiovascular and thrombotic diseases via its phenolic contents [2]. VOOs have various phenolics including phenolic acids, phenolic alcohols, glycosides, lignans, flavonoids, and secoiridoids. Phenolic content and profile can be affected by various factors such as geographical origin, olive cultivar, olive maturity stage, and extraction methods [3]. Phenolic compounds play a significant role in the taste, flavor, and antioxidant property of olive oil and these effects were reported previously [4]. They also contribute to the oxidative stability and shelf life of olive oil [3]. Oxidative damage may occur due to the excess of free radicals and this may cause increasing of the risk of various chronic diseases including atherosclerosis, chronic inflammation, and stroke. However phenolics have beneficial effect on oxidative stress and protect cell membranes from reactive free radicals and decrease LDL level [5].

Phenolic compounds in the olive fruits such as oleuropein, tyrosol, hydroxytyrosol, caffeic acid, gallic acid, syringic acid, $p$-coumaric acid, $p$-hydroxybenzoic acid, protocatechuic acid, quercetin, and luteolin show antimicrobial activity against viruses, bacteria, yeasts, and fungi $[4,6]$. In literature, 
antibacterial activities against Helicobacter pylori, Escherichia coli, Clostridium perfringens, Bacteroides sp., Streptococcus mutans, Staphylococcus aureus, Listeria monocytogenes, Yersinia sp., Salmonella enterica, Enterococcus faecium, Enterococcus faecalis, Shigella sonnei, and Candida albicans have been reported [5]. In particular, oleuropein shows antimicrobial effect on most of these microorganisms as well as on Klebsiella pneumoniae, Moraxella catarrhalis, and Salmonella typhi [7]. Karaosmanoglu et al. (2010) reported that the use of extra virgin olive oil can help to prevent foodborne diseases [4].

Mineral composition of food serves beneficial aspects for human providing positive health effects. Heavy metal content of any food is important for food hygiene, food quality, and nutrition. Olive oil includes various minerals according to the accumulation of these elements in soil with respect to natural mine sources, environmental pollution, and fertilization of trees. Olive ripeness, processing equipment, and storage supplies may also affect the composition of minerals [8]. It is known that trace metals can cause the reduction of oxidative stability of olive oil [9]. Recently, researchers aimed to evaluate if mineral composition can be used to differentiate virgin olive oils with respect to geographical origin [10].

Olive tree growing has been made in the Aegean region of Turkey for over 8,000 years [11]. Turkey is the fifth major producer of olive oil just after Spain, Greece, Italy, and Tunisia according to the 2014/2015 season when 2,444,000 tons of olive oil was produced in the world and 170,000 tons of this amount was produced in Turkey [12]. According to 2014 data, Turkey has 168,997,000 olive trees in total while 140,712 of them were bearing trees. 438,000 tons of olive fruits was used for table olive production and 1,330,000 tons of olive fruits was used for olive oil production [13]. Olive growing areas are distributed to five main regions and 28 olive varieties are cultivated commercially in Turkey. The Aegean region is the major producer and supplies $80 \%$ of the total olive oil production of Turkey. Balikesir is one of the major olive grower regions in Turkey with the ratio of $8.75 \%$ approximately in Turkey [14].

Edincik Su olive cultivar is originally grown in Edincik, Erdek, and Bandirma in Balikesir and has a large fruit with $4.90 \mathrm{~g}$ average weight, round shape, $89 \%$ pulp ratio, $17 \%$ oil content, and small seeds. This cultivar is mostly used in table olive production because of its size, shape, flavor, and high pulp ratio [15]. However using it in olive oil production has been started in recent years because of its high quality oil by the olive oil producers.

Olive cultivar, location, maturity, and extraction procedure affect the olive oil quality due to its chemical composition. Besides, geographical classification of a food has a significant role in its quality and allows for the origin authentication and traceability [16]. Based on the available literature reviewed, there is no report on the antioxidant and antimicrobial activities and mineral contents of Edincik $\mathrm{Su}$ olive oils obtained from different geographical areas produced in Turkey. Thus, this study was aimed at presenting determination of total phenolic contents, free radical scavenging activities, phenolic compositions, antimicrobial effects against fourteen pathogenic bacteria and two fungal
TABLE 1: Climatic conditions of the growing areas.

\begin{tabular}{lccc}
\hline $\begin{array}{l}\text { Annual } \\
\text { means of }\end{array}$ & $\begin{array}{c}\text { Precipitation } \\
(\mathrm{mm})\end{array}$ & $\begin{array}{c}\text { Temperature } \\
\left({ }^{\circ} \mathrm{C}\right)\end{array}$ & $\begin{array}{c}\text { Humidity } \\
(\%)\end{array}$ \\
\hline Edincik & 75.18 & 16.84 & 77.64 \\
Gomec & 77.27 & 15.18 & 60.94 \\
Izmir & 66.53 & 18.63 & 58.25 \\
\hline
\end{tabular}

strains, and mineral contents of olive oils obtained from Edincik Su cultivar in accordance to characterize these properties depending on location.

\section{Materials and Methods}

2.1. Materials. In this study, Edincik Su olive cultivars (Olea europaea L. cv. Edincik $\mathrm{Su}$ ) from three different growing regions (Edincik, Gomec, and Izmir) were used. Edincik sample was obtained from a private orchard in Edincik in Marmara region which is the origin of Edincik Su olive cultivar; Gomec sample was obtained from the orchard of Edremit Olive Generating-Training and Gene Center Directorate in Gomec in the North Aegean region; Izmir sample was obtained from orchard of the Olive Research Institute in Izmir in the middle Aegean region. Harvesting locations of Olea europaea L. cv. Edincik Su are shown in Figure 1. Climatic conditions (temperature, precipitation, and humidity) obtained from the General Directorate of Meteorology installed within the institute are given in Table 1. The olive fruits at approximately the same ripening degree were collected in December in the 2012-2013 season. The sampling was carried out according to a randomized complete block design experiment including three replicates while three olive trees were accepted as one replicate to represent the growing areas. Approximately two kilograms of olive fruits from each side and part of the trees was handpicked.

\subsection{Methods}

2.2.1. Maturity (Ripeness Index). The ripeness index (RI) was evaluated on 100 randomly selected olive fruits which is described previously [17]. The data of the olive skin and pulp colors were obtained by using the following formula while RI values range from 0 (100\% intense green skin) to 7 (100\% purple flesh and black skin):

$$
\mathrm{RI}=\frac{\left[\left(0 \mathrm{xn}_{1}\right)+\left(1 \mathrm{xn}_{2}\right)+\cdots+\left(7 \mathrm{xn}_{7}\right)\right]}{100} \text {. }
$$

2.2.2. Extraction of Virgin Olive Oil. The olive fruits which have physical damage were separated and the leaves and impurities were removed. After washing step fruits were processed mechanically by using laboratory type two-phase batch equipment (Hakki Usta Machinery, Aydin, Turkey). For this aim, firstly the leaves and impurities were removed from the fruits. Secondly the fruits were milled to obtain olive paste by using a disc miller and then the resultant paste was kneaded for 45 minutes at $27^{\circ} \mathrm{C}$ by using a malaxator (Hakki 


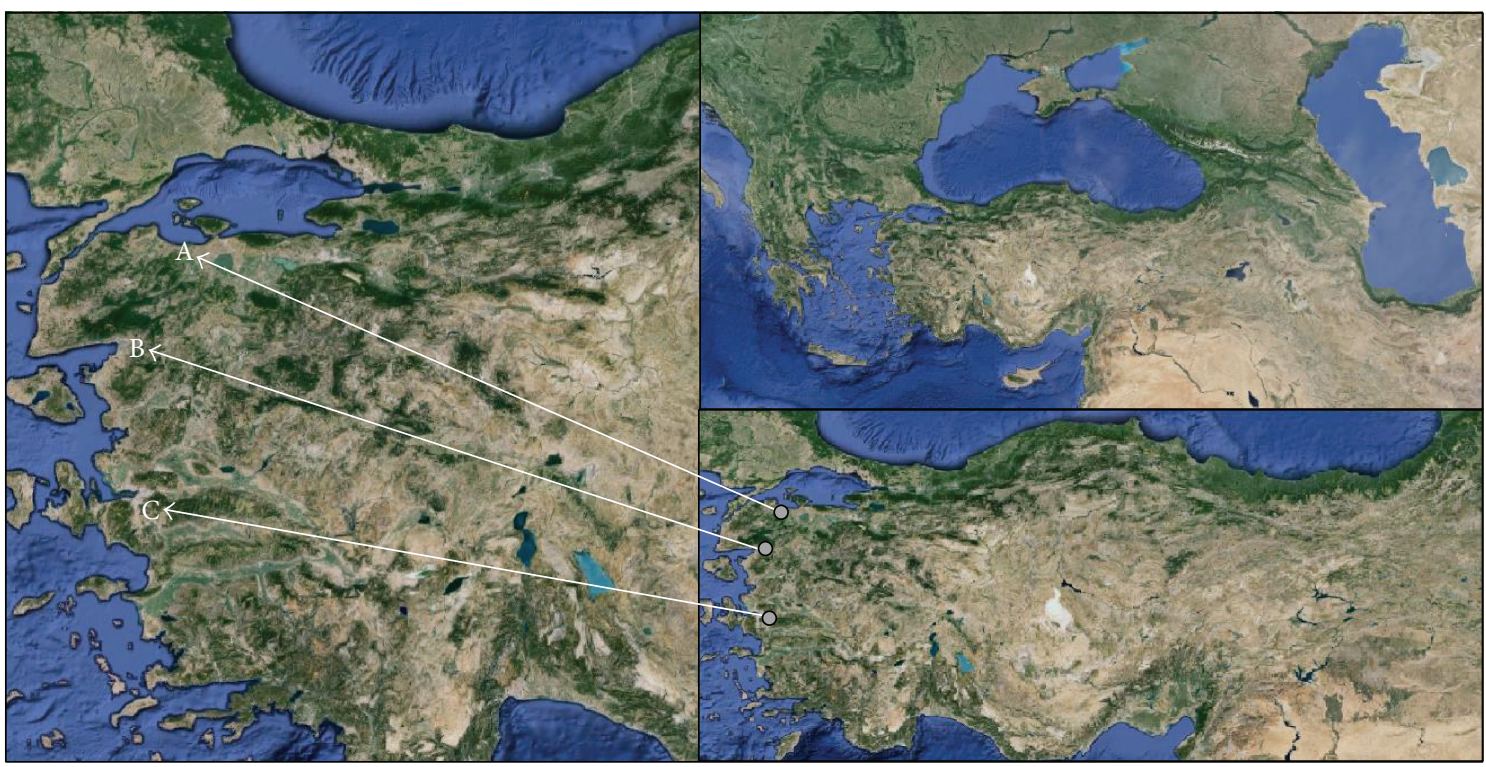

Figure 1: Harvesting locations of Olea europaea L. Edincik Su cv. fruits in Turkey: A: Edincik, B: Gomec, and C: Izmir.

Usta Machinery, Aydin, Turkey). Lastly, two-phase vertical decanter was used for the centrifugation of paste (Hakki Usta Machinery, Aydin, Turkey). The anhydrous form of magnesium sulfate was added to the separated oil to remove the residual water. Finally, the oil was filtered through the cotton and rough filter paper by using a vacuum pump. Virgin olive oil samples were stored in a freezer at $-20^{\circ} \mathrm{C}$ until their analysis.

\subsubsection{Antioxidant Activity}

Determination of Total Phenolic Content (TPC). The phenolics of the olive oil samples were extracted by liquid/liquid extraction method using methanol/water solution $(40: 60$, $\mathrm{vol} / \mathrm{vol}$ ). TPC of the extracts was identified by Folin-Ciocalteu spectrophotometric (T70 + UV/VIS spectrophotometer, PG Instruments, England) method at $765 \mathrm{~nm}$ [18]. The results were described as milligrams of gallic acid equivalent (GAE) per kilogram of oil while gallic acid calibration curve was evaluated $\left(r^{2}=0.999\right)$. The spectrophotometric analysis was performed in triplicate.

Free Radical Scavenging Activity (FRSA). Antioxidant activities of phenolic extracts were identified with the method of 2,2-diphenyl-1-picrylhydrazyl ( $\mathrm{DPPH}^{*}$ ) radical scavenging activity described by Dorman et al. (2003) [19]. The results were given as inhibition value (\%) of $\mathrm{DPPH}^{*}$ radical Tris$\mathrm{HCl}$ buffer $(50 \mathrm{mM}, \mathrm{pH} 7.4)$ including phenolic extract of virgin olive oil $(50 \mu \mathrm{L})$ was mixed with buffer solution of tris- $\mathrm{HCl}(450 \mu \mathrm{L}, 50 \mathrm{mM})$ and $\mathrm{DPPH}^{\bullet}$ radical in methanol $(1.0 \mathrm{~mL}, 0.1 \mathrm{mM})$. This mixture was stored for incubation in the dark and at ambient temperature conditions during 30 minutes. The absorbance of the resultant was recorded at
$517 \mathrm{~nm}$. The results were given as percentage inhibition which was calculated using the following equation:

inhibition (\%)

$$
\begin{aligned}
= & {\left[\frac{(\text { absorbance of control }- \text { absorbance of sample })}{\text { absorbance of control }}\right] } \\
& \times 100 .
\end{aligned}
$$

Estimated inhibition of $\mathrm{DPPH}^{*}$ radical (\%) values is given as the average of quadruplicate analyses.

Analysis of Phenolic Compounds. The phenolic profiles of VOO samples were identified according to the method described by Caponio et al. (1999) [20] with some modifications. A liquid/liquid extraction method by methanol/water $(40: 60, \mathrm{vol} / \mathrm{vol})$ mixture was performed for the extraction of the individual phenolic compounds. Rotary evaporator was used at $35^{\circ} \mathrm{C}$ under vacuum to evaporate the solvent phase. After dissolving residue in methanol, this fraction was filtered by a $0.45 \mu \mathrm{m}$ pore size membrane filter (Vivascience AG, Hannover, Germany). The analysis was carried out with a SCL-10Avp system controller, a SIL-10AD vp autosampler, a CTO-10Avp column heater, a DGU-14a degasser, an LC$10 \mathrm{AD}$ vp pump, and a diode array detector with wavelengths at $278 \mathrm{~nm} .5 \mu \mathrm{m}$ column filled with $5 \mu$ Luna Prodigy with 250 $\times 4,6 \mathrm{~mm}$ i.d. was used. $1 \mathrm{~mL} / \mathrm{min}$ flow rate, $10 \mu \mathrm{L}$ injection volume, and $30^{\circ} \mathrm{C}$ column temperature were performed. Acetic acid:water $(2: 98 \mathrm{v} / \mathrm{v})$ and methanol were used as gradient elution. The gradient program is given in Table 2. Shimadzu Class-VP Chromatography Laboratory Automated Software system was used to evaluate the data. External calibration curves were used to identify phenolic component contents in the extracts as $\mathrm{mg} \mathrm{kg}^{-1}$ oil. All determinations 
TABLE 2: Solvent gradient conditions with linear gradient*

\begin{tabular}{lcccccccccc}
\hline Final time (min) & 3 & 20 & 28 & 35 & 45 & 60 & 62 & 70 & 75 & 80 \\
\hline A\% & 95 & 75 & 72 & 70 & 65 & 63 & 55 & 50 & 20 & 0 \\
B\% & 5 & 25 & 28 & 30 & 35 & 37 & 45 & 50 & 80 & 100 \\
\hline
\end{tabular}

${ }^{*} \mathrm{~A}($ solvent $)=$ acetic acid $:$ water $(2: 98, \mathrm{v} / \mathrm{v}) ; \mathrm{B}($ solvent $)=$ methanol.

were performed in triplicate and the average results were given.

\subsubsection{Antimicrobial Activity}

Test Microorganisms. Fourteen pathogenic bacteria and two fungal strains were used as test microorganisms as follows: Acinetobacter baumannii ATCC 19606, Bacillus cereus ATCC 11778, Campylobacter jejuni ATCC 33291, Candida albicans ATCC 10231, Clostridium perfringens ATCC 13124, Enterobacter sakazakii ATCC 51329, Enterococcus faecalis ATCC 29212, Escherichia coli ATCC 25922, Klebsiella pneumoniae ATCC 31488, Proteus vulgaris ATCC 49132, Pseudomonas aeruginosa ATCC 27853, Saccharomyces cerevisiae ATCC 4098, Salmonella typhimurium ATCC 14028, Shigella sonnei ATCC 25931, Staphylococcus aureus ATCC 25923, and Yersinia enterocolitica ATCC 23715.

Analysis of Antimicrobial Activity. The antimicrobial activity of phenolic extracts was determined by using the disc diffusion method applied by Obied et al. (2007) [21]. MuellerHinton $(\mathrm{MH})$ agar (Oxoid) was used for bacteria and $\mathrm{MH}$ agar with $2 \%$ glucose plus $0.5 \mu \mathrm{g} / \mathrm{mL}$ methylene blue was used for fungi. $\mathrm{MH}$ agar was only enriched with $5 \%(\mathrm{v} / \mathrm{v})$ defibrinated sheep blood for $C$. jejuni. All the microorganisms were cultured overnight in trypticase soy broth (Oxoid) at $25^{\circ} \mathrm{C} \pm 1$ and $37^{\circ} \mathrm{C} \pm 1$ for fungi and bacteria, respectively. The turbidity of the culture suspensions was adjusted to the McFarland 0.5 turbidity standard and was used as inoculum. The phenolic extracts were prepared with absolute ethanol and absorbed $(30 \mu \mathrm{L})$ onto the blank sensitivity discs, $6 \mathrm{~mm}$ (Oxoid), then left to dry in a sterile Petri dish for $90 \mathrm{~min}$. The same volume $(30 \mu \mathrm{L})$ of absolute ethanol was used as a control. Gentamicin ( $30 \mu \mathrm{g}$, Oxoid) was employed as a positive control. The suspensions of microorganisms were inoculated $(100 \mu \mathrm{L})$ on plates containing MH agar, and the inoculum was immediately and evenly distributed with a Drigalski spatula. The discs containing the extracts were performed on the surface of the plates containing each inoculate. The plates incubated at $25^{\circ} \mathrm{C} \pm 1$ for $24 \mathrm{~h}$ under aerobic conditions for fungi and $37^{\circ} \mathrm{C} \pm 1$ for $24 \mathrm{~h}$ under aerobic conditions for bacteria except C. jejuni and C. perfringens. For C. jejuni and $C$. perfringens, plates incubated under microaerophilic (Oxoid, BR60) and anaerobic (Oxoid, AN25) conditions, respectively. After this period, they were inspected for the presence of inhibition zones and these, when present, were measured with a ruler (in $\mathrm{mm}$ ). The analysis was repeated at least three times for each sample against all microorganisms.

Determination of Mineral Contents. Decomposition of oil samples was achieved using microwave assisted digestion
TABLE 3: Microwave digestion procedure.

\begin{tabular}{lcccc}
\hline Stage & $\begin{array}{c}\text { Ramp time } \\
(\mathrm{min})\end{array}$ & $\begin{array}{c}\text { Maximum } \\
\text { pressure } \\
(\mathrm{psi})\end{array}$ & $\begin{array}{c}\text { Temperature } \\
\left({ }^{\circ} \mathrm{C}\right)\end{array}$ & $\begin{array}{c}\text { Hold } \\
\text { time } \\
(\mathrm{min})\end{array}$ \\
\hline 1 & 10 & 140 & 130 & 10 \\
2 & 10 & 200 & 150 & 10 \\
$\begin{array}{l}\text { Cooling for 10 } \\
\text { minutes }\end{array}$ & & & & \\
3 & 20 & 200 & 160 & 20 \\
\hline
\end{tabular}

system. Accordingly, $0.5 \mathrm{~g}$ of oil sample was weighed in polytetrafluoroethylene vessel and $10 \mathrm{~mL}$ of concentrated $\mathrm{HNO}_{3}$ was added. Digestion of the samples was completed according to the procedure given in Table 3 [22]. After the vessels had cooled, the solutions were transferred to a volumetric flask and diluted up to $25.0 \mathrm{~mL}$ prior to ICP-OES analysis.

2.3. Statistical Analysis. All parameters were identified in triplicate for each sample. Statistical analyses were processed by SPSS statistical package (IBM SPSS Statistics 21). Results were determined by one-way analysis of variance (ANOVA), using Duncan's multiple range tests. A significant difference among data was evaluated at $95 \%, 99 \%$, and $99.9 \%$ of confidences ( $p \leq 0.05, p \leq 0.01$, and $p \leq 0.001$ ).

\section{Results and Discussion}

The ripeness indexes of the olive fruits were close to each other to evaluate them at the same maturation degree. The results were 5.71, 5.57, and 5.30 for Edincik, Gomec, and Izmir samples, respectively. The maturity of the olive fruit was attributed by qualitative assessment of the pigmentation of the olive skin and pulp and used by the olive oil industry as a common marker for the degree of ripeness [23]. While the oil content increases in the olive anthocyanins accumulate while photosynthetic activity decreases and causes the decrease of pigments such as chlorophylls and carotenoids [24]. Ripeness index, total phenolic contents, and free radical scavenging activities of the samples are shown in Figure 2.

3.1. Total Phenolic Contents and Antioxidant Activities. Total phenolic contents of the samples were found to be 189.64 , 71.99, and $185.50 \mathrm{mg}$ GAE/kg olive oil of Edincik, Gomec, and Izmir samples, respectively. Total phenolic content of the olive fruit and olive oil is affected by some agronomic and processing factors. In particular, maturity of the fruits and water availability of the trees as agronomic factors have significant effects on the TPC which were also reported previously [25]. In particular less precipitation affects the plant tissues to be in stress and thus polyphenol production increases [26]. In the present study, the least annual precipitation was recorded in Izmir $(66.53 \mathrm{~mm})$. TPC of this sample was found to be the second highest amount and antiradical activity was found to be the highest. TPC result of this sample may be affected by some agricultural cultivation practices [16]. Considering the data of both climatic conditions and TPC, it is clearly 


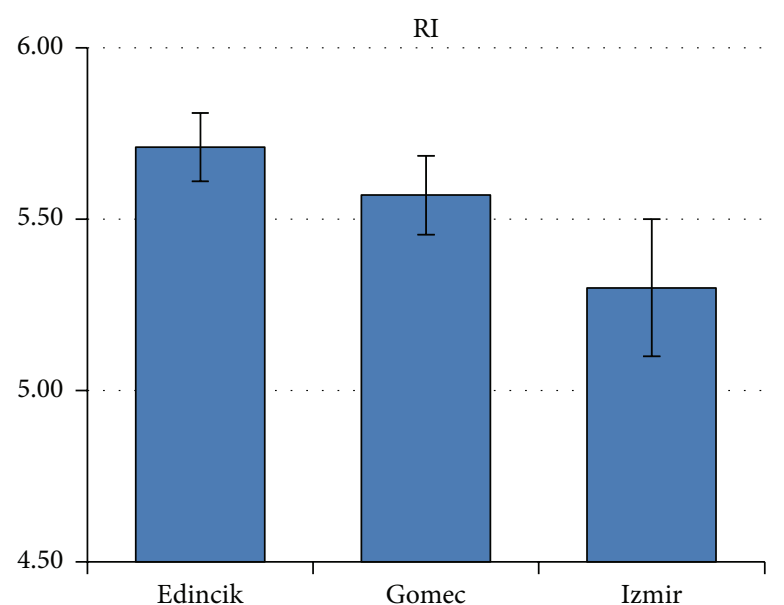

FRSA

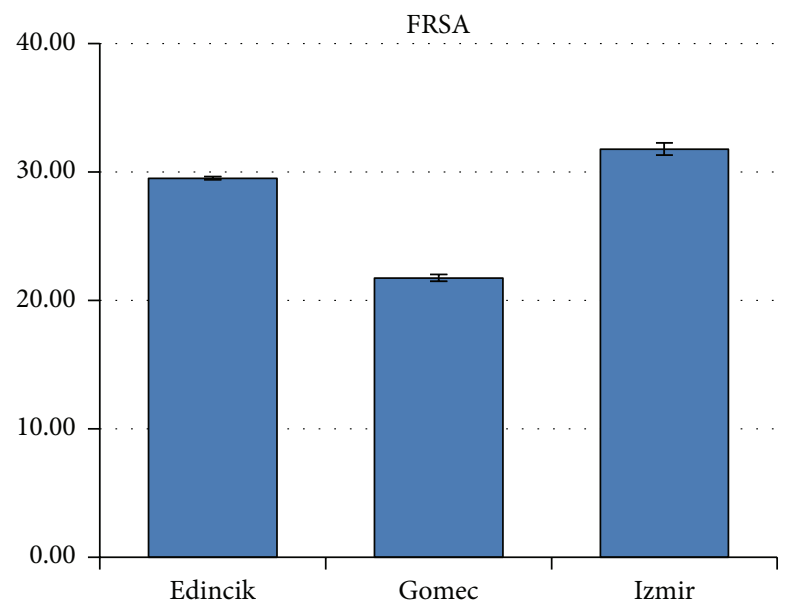

TPC

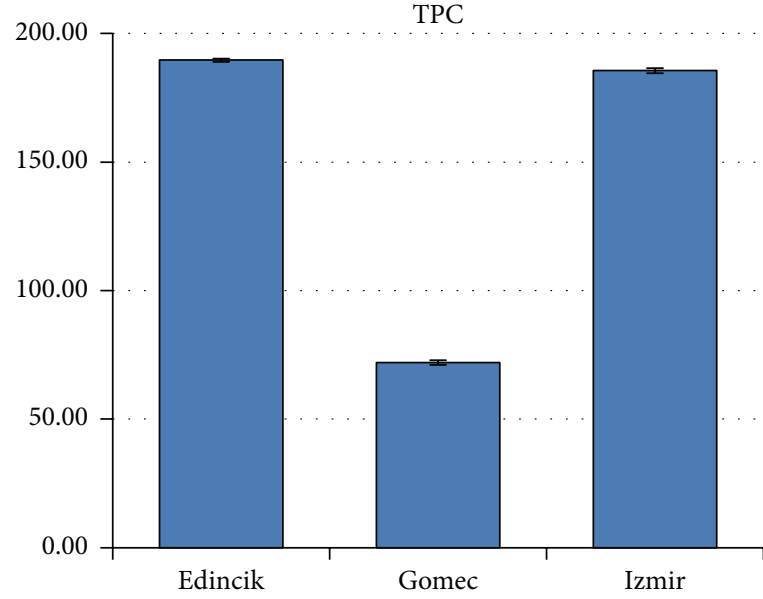


TABLE 4: Phenolic compounds of virgin olive oil samples ( $\mathrm{mg} / \mathrm{kg})$.

\begin{tabular}{lccc}
\hline Phenolic compounds & \multicolumn{3}{c}{ Samples } \\
& Edincik & Gomec & Izmir \\
\hline Hydroxytyrosol & $36.38 \pm 0.30^{\mathrm{a} *}$ & $25.96 \pm 0.46^{\mathrm{b}}$ & $59.00 \pm 0.40^{\mathrm{c}}$ \\
Tyrosol & $43.66 \pm 0.26^{\mathrm{a}}$ & $33.73 \pm 0.13^{\mathrm{c}}$ & $18.16 \pm 0.16^{\mathrm{b}}$ \\
Vanillic acid & $1.14 \pm 0.14^{\mathrm{b}}$ & $2.24 \pm 0.12^{\mathrm{a}}$ & $0.70 \pm 0.10^{\mathrm{c}}$ \\
Vanillin & $0.33 \pm 0.02^{\mathrm{a}}$ & $0.27 \pm 0.02^{\mathrm{a}}$ & $0.26 \pm 0.06^{\mathrm{a}}$ \\
p-Coumaric acid & $0.40 \pm 0.03^{\mathrm{b}}$ & $1.24 \pm 0.02^{\mathrm{a}}$ & $0.12 \pm 0.01^{\mathrm{c}}$ \\
Ferulic acid & $0.12 \pm 0.07^{\mathrm{b}}$ & $0.27 \pm 0.01^{\mathrm{a}}$ & $0.04 \pm 0.01^{\mathrm{b}}$ \\
Cinnamic acid & $0.10 \pm 0.00^{\mathrm{b}}$ & $0.20 \pm 0.02^{\mathrm{a}}$ & $0.11 \pm 0.01^{\mathrm{b}}$ \\
Quercetin & $1.09 \pm 0.05^{\mathrm{a}}$ & $1.05 \pm 0.05^{\mathrm{a}}$ & $1.04 \pm 0.04^{\mathrm{a}}$ \\
Luteolin & $1.52 \pm 0.11^{\mathrm{b}}$ & $2.48 \pm 0.07^{\mathrm{a}}$ & $0.87 \pm 0.70^{\mathrm{c}}$ \\
\hline
\end{tabular}

${ }^{*}$ Differences between means indicated by the same letters are not statistically significant $(p \leq 0.05)$.

that the antioxidant capacities of olive oil extracts of the Ayvalik olive cultivar varied according to the geographical origin [35]. Ögütçü and Yılmaz (2009) also reported that antioxidant capacities of olive oils changed (0.60-5.34 mmol Trolox equivalents) with respect to the regions [36]. Del Monaco et al. (2015) reported FRSA of different olive cultivars (Lavagnina cv., Taggiasca cv., Leccino cv., and Cerasuola cv.) according to the locations between 70 and $76 \%, 74$ and $76 \%$, 72 and $79 \%$, and 73 and $82 \%$ inhibition of $\mathrm{DPPH}^{\circ}$ radical values, respectively [31]. The unripe and ripe fruits from Chemlali and Neb Jmel were studied to determine FRSA which was found to be $93.94-96.68 \%$ and $57.95-93.94 \%$, respectively [37]. Uğurlu Aşık and Ozkan (2011) found FRSA of Memecik cultivar to be 9.55 FRSA (\% inhibition of DPPH ${ }^{\bullet}$ radical) in Turkey [28]. Karaosmanoglu et al. (2010) carried out the research in Turkey by using nine olive cultivars [4]. They determined FRSA between 5.34\% and $21.97 \%$. Issaoui et al. (2010) determined lower antioxidant activities $\left(\mathrm{EC}_{50}(\mathrm{mg} / \mathrm{kg})\right.$ and ABTS $\left.(\mathrm{mM})\right)$ while TPC of the same samples were higher [32]. Our results were in accordance with these results. According to Brahmi et al. (2013) antioxidative property of olive and olive oil depends on the location and olive maturity [37]. Besides Yildiz and Uylaşer (2015) stated that antioxidant capacity of olives is not related to their phenolics content, but it is more related to the olive type [38].

3.2. Phenolic Profiles of Virgin Olive Oils. The individual phenolic compounds of the olive oil samples are given in Table 4. Nine different phenolic compounds were detected and quantified while hydroxytyrosol and tyrosol were determined as abundant compounds. Similar results were reported for Turkish olive cultivars previously [39]. Hydroxytyrosol content of the samples was found between 25.96 and $59.00 \mathrm{mg} / \mathrm{kg}$ and tyrosol was detected between 18.16 and $43.66 \mathrm{mg} / \mathrm{kg}$. Luteolin, quercetin, and vanillic acid were close to each other with the concentration ranged between 0.87 and $2.48,1.04$ and 1.09 , and 0.70 and $2.24 \mathrm{mg} / \mathrm{kg}$, respectively. The least amount was observed for cinnamic acid with the range of 0.10 and $0.20 \mathrm{mg} / \mathrm{kg}$. ANOVA results of the samples due to the phenolic composition of the samples are presented in Table 6 . As can be seen from the table, statistically significant differences were evaluated at $0.1 \%$ confidence $(p \leq 0.001)$ for hydroxytyrosol, tyrosol, vanillic acid, $p$-coumaric acid, ferulic acid, cinnamic acid, and luteolin while there was no statistical difference for vanillin and quercetin. Phenolic compositions of VOOs can be used as classifier according to the geographical origin [40]. Kelebek et al. (2012) reported 13 phenolic compounds in Gemlik olive cv. from Turkey while hydroxytyrosol, tyrosol, and luteolin contents were detected as $3.21 \mathrm{mg} / \mathrm{kg}, 9.85 \mathrm{mg} / \mathrm{kg}$, and $1.28 \mathrm{mg} / \mathrm{kg}$, respectively [33]. Our results were higher with respect to hydroxytyrosol and tyrosol contents of Ayvalik olive cv. while 0.5-4.9 and 1.0$4.2 \mathrm{mg} / \mathrm{kg}$ were reported by the researchers, respectively [11]. Similarly Alkan et al. (2012) found hydroxytyrosol and tyrosol contents were less than our results. They carried out the study in two different crop seasons and reported hydroxytyrosol and tyrosol contents between 3.16 and 4.27 and 1.70 and $6.96 \mathrm{mg} / \mathrm{kg}$ for the 2005 year and 3.89 and 7.36 and 4.92 and $10.67 \mathrm{mg} / \mathrm{kg}$ for the 2006 year, respectively [41]. Bayram et al. (2012) indicated that the phenolic compositions of olive oil samples of the Ayvalik olive cultivar varied according to the geographical origin. The results were given for hydroxytyrosol and tyrosol contents between 2.8 and $3.8 \mathrm{mg} / \mathrm{kg}$ and 3.1 and $6.7 \mathrm{mg} / \mathrm{kg}$, respectively [42]. In another study in which Ayvalık cv. was studied, hydroxytyrosol and tyrosol contents were varied and quantified between 0.26 and 1.1 and 0.45 and 0.67 . Phenolic profiles of Gemlik cv. were also varied according to the growing localities [43]. The variability of phenolic compositions of Ayvalık and Memecik cultivars according to the growing provinces was reported in the study carried out by Ilyasoglu et al. (2010) [44].

3.3. Antimicrobial Activities of Phenolic Extracts. Antimicrobial activities of the phenolic extracts of olive oils are presented in Table 5. The inhibition zones formed by the phenolic extracts against the tested microorganisms were altered between $7.00 \mathrm{~mm}$ and $15.67 \mathrm{~mm}$. The highest antimicrobial activity was observed against Clostridium perfringens ATCC 13124 including $15.67 \mathrm{~mm}$ inhibition zones for Edincik and Gomec samples and $15.33 \mathrm{~mm}$ inhibition zones for Izmir sample. The second highest values were evaluated for Campylobacter jejuni ATCC 33291 with $11.33 \mathrm{~mm}$ inhibition zones for all samples. The third one can be said to be Candida albicans ATCC 10231 and the values were as the following: $10.33 \mathrm{~mm}$ inhibition zone for Edincik sample, $11.00 \mathrm{~mm}$ inhibition zone for Gomec sample, and $8.33 \mathrm{~mm}$ inhibition zone for Izmir sample. The same inhibition zones were evaluated for Klebsiella pneumoniae ATCC 31488 with $7.67 \mathrm{~mm}$ for all samples. Proteus vulgaris ATCC 29905, Staphylococcus aureus ATCC 6538, and Saccharomyces cerevisiae ATCC 9763 were the least susceptible microorganisms to the phenolic extracts of all samples as can be seen in Table 5 .

If the data is considered separately, it can be concluded that Edincik sample showed the highest antimicrobial activity against Clostridium perfringens ATCC 13124, Salmonella typhimurium ATCC 14028, Campylobacter jejuni ATCC 33291, Shigella sonnei ATCC 25931, and Candida albicans ATCC 10231 while no antimicrobial effect was detected on Enterococcus faecalis ATCC 19433 and Escherichia coli ATCC 
TABLE 5: Antimicrobial activities of the phenolic extracts of virgin olive oils.

\begin{tabular}{|c|c|c|c|c|}
\hline \multirow[b]{2}{*}{ Microorganisms } & \multicolumn{4}{|c|}{ Inhibition zones $(\mathrm{mm})$} \\
\hline & Edincik & Gomec & Izmir & $\begin{array}{c}\text { Antibiotic } \\
\text { (Gentamicin) }\end{array}$ \\
\hline $\begin{array}{l}\text { Enterococcus faecalis ATCC } 19433 \\
\text { (Gram-positive) }\end{array}$ & $0.00 \pm 0.00^{\mathrm{b}^{*}}$ & $7.67 \pm 0.58^{\mathrm{a}}$ & $8.33 \pm 0.58^{\mathrm{a}}$ & $21.00 \pm 1.00^{* *}$ \\
\hline $\begin{array}{l}\text { Salmonella typhimurium ATCC } 14028 \\
\text { (Gram-negative) }\end{array}$ & $11.67 \pm 0.58^{\mathrm{a}}$ & $7.33 \pm 0.58^{\mathrm{b}}$ & $8.33 \pm 0.58^{\mathrm{b}}$ & $19.00 \pm 1.00$ \\
\hline $\begin{array}{l}\text { Enterobacter sakazakii ATCC } 51329 \\
\text { (Gram-negative) }\end{array}$ & $7.33 \pm 0.58^{\mathrm{b}}$ & $8.33 \pm 0.58^{\mathrm{a}}$ & $8.00 \pm 0.00^{\mathrm{ab}}$ & $23.67 \pm 3.51$ \\
\hline Proteus vulgaris ATCC 29905 (Gram-negative) & $7.00 \pm 0.00^{\mathrm{b}}$ & $7.33 \pm 0.58^{\mathrm{b}}$ & $9.33 \pm 0.58^{\mathrm{a}}$ & $17.00 \pm 1.00$ \\
\hline $\begin{array}{l}\text { Pseudomonas aeruginosa ATCC } 27853 \\
\text { (Gram-negative) }\end{array}$ & $7.33 \pm 0.58^{\mathrm{c}}$ & $11.33 \pm 0.58^{\mathrm{a}}$ & $10.00 \pm 0.00^{\mathrm{b}}$ & $24.00 \pm 2.00$ \\
\hline Bacillus cereus ATCC 11778 (Gram-positive) & $9.33 \pm 0.58^{\mathrm{b}}$ & $11.67 \pm 0.58^{\mathrm{a}}$ & $8.67 \pm 0.58^{\mathrm{b}}$ & $19.00 \pm 1.00$ \\
\hline $\begin{array}{l}\text { Staphylococcus aureus ATCC } 6538 \\
\text { (Gram-positive) }\end{array}$ & $7.67 \pm 0.58^{\mathrm{a}}$ & $7.33 \pm 0.58^{\mathrm{a}}$ & $7.33 \pm 0.58^{\mathrm{a}}$ & $23.00 \pm 2.65$ \\
\hline $\begin{array}{l}\text { Klebsiella pneumoniae ATCC } 31488 \\
\text { (Gram-negative) }\end{array}$ & $7.67 \pm 0.58^{\mathrm{a}}$ & $7.67 \pm 0.58^{\mathrm{a}}$ & $7.67 \pm 0.58^{\mathrm{a}}$ & $22.67 \pm 2.08$ \\
\hline Escherichia coli ATCC 25292 (Gram-negative) & $0.00 \pm 0.00^{\mathrm{c}}$ & $11.33 \pm 0.58^{\mathrm{a}}$ & $10.33 \pm 0.58^{\mathrm{b}}$ & $19.67 \pm 0.58$ \\
\hline Shigella sonnei ATCC 25931 (Gram-negative) & $10.67 \pm 0.58^{\mathrm{a}}$ & $8.67 \pm 0.58^{\mathrm{b}}$ & $8.67 \pm 0.58^{\mathrm{b}}$ & $22.33 \pm 0.58$ \\
\hline $\begin{array}{l}\text { Yersinia enterocolitica ATCC } 23715 \\
\text { (Gram-negative) }\end{array}$ & $7.33 \pm 0.58^{\mathrm{b}}$ & $7.67 \pm 0.58^{\mathrm{ab}}$ & $8.67 \pm 0.58^{\mathrm{a}}$ & $26.67 \pm 0.58$ \\
\hline $\begin{array}{l}\text { Clostridium perfringens ATCC } 13124 \\
\text { (Gram-positive) }\end{array}$ & $15.67 \pm 0.58^{\mathrm{a}}$ & $15.67 \pm 0.58^{\mathrm{a}}$ & $15.33 \pm 0.58^{\mathrm{a}}$ & $24.33 \pm 0.58$ \\
\hline $\begin{array}{l}\text { Campylobacter jejuni ATCC } 33291 \\
\text { (Gram-negative) }\end{array}$ & $11.33 \pm 1.15^{\mathrm{a}}$ & $11.33 \pm 0.58^{\mathrm{a}}$ & $11.33 \pm 0.58^{\mathrm{a}}$ & $26.67 \pm 1.15$ \\
\hline $\begin{array}{l}\text { Acinetobacter baumannii ATCC } 19606 \\
\text { (Gram-negative) }\end{array}$ & $8.67 \pm 0.58^{\mathrm{b}}$ & $10.33 \pm 0.58^{\mathrm{a}}$ & $9.00 \pm 0.00^{\mathrm{b}}$ & $22.00 \pm 0.00$ \\
\hline Candida albicans ATCC $10231(-)$ & $10.33 \pm 0.58^{\mathrm{a}}$ & $11.00 \pm 1.00^{\mathrm{a}}$ & $8.33 \pm 0.58^{\mathrm{b}}$ & $24.33 \pm 0.58$ \\
\hline Saccharomyces cerevisiae ATCC $9763(-)$ & $7.33 \pm 0.58^{\mathrm{a}}$ & $7.00 \pm 0.00^{\mathrm{a}}$ & $7.00 \pm 0.00^{\mathrm{a}}$ & $0.00 \pm 0.00$ \\
\hline
\end{tabular}

${ }^{*}$ Differences between means indicated by the same letters are not statistically significant $(p \leq 0.05) .{ }^{* *}$ Antibiotic was used as a positive control and was not evaluated statistically.

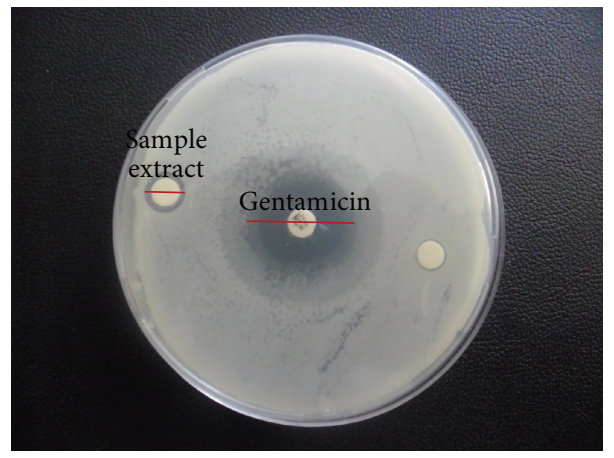

FIGURE 3: Inhibition zones of phenolic extracts and antibiotic (Gentamicin) against Pseudomonas aeruginosa ATCC 27853.

25292 as shown in Table 5. Gomec sample had the highest antimicrobial activity against Clostridium perfringens ATCC 13124, Bacillus cereus ATCC 11778, Campylobacter jejuni ATCC 33291, Escherichia coli ATCC 25292, and Pseudomonas aeruginosa ATCC 27853 (inhibition zones of phenolic extract and antibiotic are shown in Figure 3) and Candida albicans ATCC 10231. Lastly, Izmir sample had the highest activity against Clostridium perfringens ATCC 13124, Campylobacter jejuni ATCC 33291, and Escherichia coli ATCC 25292. Gentamicin as a reference antibiotic had the highest effect on Yersinia enterocolitica ATCC 23715 and Campylobacter jejuni ATCC 33291 while it had no effect on Saccharomyces cerevisiae ATCC 9763. ANOVA results of the phenolic extracts with respect to the antimicrobial activity are presented in Table 6. Statistically significant differences were evaluated at $0.1 \%$ confidence $(p \leq 0.001)$ against Enterococcus faecalis 
TABLE 6: ANOVA results of antimicrobial activity of phenolic extracts of virgin olive oils and phenolic compounds.

\begin{tabular}{|c|c|c|c|c|}
\hline & Sum of squares & $\mathrm{df}$ & Mean square & $F$ \\
\hline \multicolumn{5}{|l|}{ Microorganisms } \\
\hline Enterococcus faecalis ATCC 19433 & 128.667 & 2 & 64,333 & $289.500^{* * *}$ \\
\hline Salmonella typhimurium ATCC 14028 & 30.889 & 2 & 15.444 & $46.333^{* * *}$ \\
\hline Enterobacter sakazakii ATCC 51329 & 1.556 & 2 & 0.778 & 3.5 \\
\hline Proteus vulgaris ATCC 29905 & 9.556 & 2 & 4.778 & $21.500^{* *}$ \\
\hline Pseudomonas aeruginosa ATCC 27853 & 24.889 & 2 & 12.444 & $56.000^{* * *}$ \\
\hline Bacillus cereus ATCC 11778 & 14.889 & 2 & 7.444 & $22.333^{* *}$ \\
\hline Staphylococcus aureus ATCC 6538 & 0.222 & 2 & 0.111 & 0.333 \\
\hline Klebsiella pneumoniae ATCC 31488 & 0.000 & 2 & 0.000 & 0.000 \\
\hline Escherichia coli ATCC 25292 & 236.222 & 2 & 118.111 & $531.500^{* * *}$ \\
\hline Shigella sonnei ATCC 25931 & 8.000 & 2 & 4.000 & $12.000^{* *}$ \\
\hline Yersinia enterocolitica ATCC 23715 & 2.889 & 2 & 1.444 & 4.333 \\
\hline Clostridium perfringens ATCC 13124 & 0.222 & 2 & 0.111 & 0.333 \\
\hline Campylobacter jejuni ATCC 33291 & 0.000 & 2 & 0.000 & 0.000 \\
\hline Acinetobacter baumannii ATCC 19606 & 4.667 & 2 & 2.333 & $10.500^{*}$ \\
\hline Candida albicans ATCC 10231 & 11.556 & 2 & 5.778 & $10.400^{*}$ \\
\hline Saccharomyces cerevisiae ATCC 9763 & 0.222 & 2 & 0.111 & 1.000 \\
\hline \multicolumn{5}{|l|}{ Phenolic compounds } \\
\hline Hydroxytyrosol & 1711.88 & 2 & 855.941 & $5562.876^{* * *}$ \\
\hline Tyrosol & 991.280 & 2 & 495.640 & $13505.174^{* * *}$ \\
\hline Vanillic acid & 3.775 & 2 & 1.888 & $128.700^{* * *}$ \\
\hline Vanillin & 0.009 & 2 & 0.004 & 2.932 \\
\hline$p$-Coumaric acid & 2.038 & 2 & 1.019 & $2184.000^{* * *}$ \\
\hline Ferulic acid & 0.041 & 2 & 0.021 & $228.333^{* * *}$ \\
\hline Cinnamic acid & 0.018 & 2 & 0.009 & $54.600^{* * *}$ \\
\hline Quercetin & 0.04 & 2 & 0.002 & 0.955 \\
\hline Luteolin & 3.936 & 2 & 1.968 & $252.321^{* * *}$ \\
\hline
\end{tabular}

${ }^{* * *}$ Statistically significant $(p \leq 0.001),{ }^{* *}$ statistically significant $(p \leq 0.01)$, and ${ }^{*}$ statistically significant $(p \leq 0.05)$.

ATCC 19433, Salmonella typhimurium ATCC 14028, Pseudomonas aeruginosa ATCC 27853, and Escherichia coli ATCC 25292; at $1 \%$ confidence ( $p \leq 0.01$ ) against Proteus vulgaris ATCC 29905, Bacillus cereus ATCC 11778, and Shigella sonnei ATCC 25931; at 5\% confidence $(p \leq 0.05)$ against Acinetobacter baumannii ATCC 19606 and Candida albicans ATCC 10231 among different location samples. The descending rank of the antimicrobial activities was Gomec, Izmir, and Edincik samples. Therefore it can be said that location has a significant effect on the antimicrobial activities of the phenolic extracts of olive oils. It is reported that phenolic components have more antimicrobial effects against Gram-positive bacteria than Gram-negative bacteria [45]. Karaosmanoglu et al. (2010) reported that the antimicrobial activities of olive oils obtained from different regions (Burhaniye, Dalaman, and Nizip) were different as $0.22,5.03$, and 5.99 values of initial bacterial concentration in test tube $\left(5 \times 10^{6} \mathrm{cfu} / \mathrm{mL}\right)$ against Escherichia coli [4]. In another study, caffeic acid as a phenolic compound was determined to be an antimicrobial agent against Bacillus cereus KCCM 40935 and Escherichia coli KCCM 11234 with $9.8 \mathrm{~mm}$ and $10.1 \mathrm{~mm}$ inhibition zones values, respectively [46]. In addition to these, it is observed that there are more studies investigating antimicrobial activities of olive leaves than olive oils.

3.4. Mineral Contents of Virgin Olive Oils. It can be possible to determine freshness, toxicological qualities, and oxidative stabilities of olive oils by identification of mineral contents [8]. Some trace metal contents present at low concentration ratios in oils and this fact causes difficulty of determination [47]. In this study we used 16 different minerals while eleven of them were heavy metals. The mineral contents of virgin olive oils are given in Table 7 . Edincik sample had $2.16 \mu \mathrm{g} / \mathrm{g}$ $\mathrm{Mg}$ and $10.84 \mu \mathrm{g} / \mathrm{g} \mathrm{K}$ and Gomec sample had $0.33 \mu \mathrm{g} / \mathrm{g} \mathrm{Fe}$, $6.14 \mu \mathrm{g} / \mathrm{g} \mathrm{Mg}, 1.47 \mu \mathrm{g} / \mathrm{g} \mathrm{Sn}, 34.59 \mu \mathrm{g} / \mathrm{g} \mathrm{K}$, and $2.22 \mu \mathrm{g} / \mathrm{g} \mathrm{Ca}$ while no mineral content was detected in Izmir sample. Only $\mathrm{Fe}$ and $\mathrm{Sn}$ were found as heavy metals in Gomec sample in low concentrations. These differences may be due to affected soil types regarding natural mine sources, environmental pollution, and fertilization of trees [8].

Cindric et al. (2007) characterized trace elements in edible oils by ICP-AES and found $14.2-16.6 \mu \mathrm{g} / \mathrm{g}$ of Fe content, $3.2-3.8 \mu \mathrm{g} / \mathrm{g}$ of $\mathrm{Mg}$ content, $1.8-2.2 \mu \mathrm{g} / \mathrm{g}$ of Ca content, and $<0.3 \mu \mathrm{g} / \mathrm{g}$ K content [48]. Arslan and Özcan (2011) reported 
TABLE 7: Mineral contents of virgin olive oils by ICP-OES ( $\mu \mathrm{g} / \mathrm{g})$.

\begin{tabular}{lcccccc}
\hline \multirow{2}{*}{ Minerals } & \multicolumn{2}{c}{ Edincik } & \multicolumn{2}{c}{ Gomec } & \multicolumn{2}{c}{ Izmir } \\
& Mean & SD $^{\mathrm{c}}$ & Mean & SD & Mean & SD \\
\hline $\mathrm{Fe}^{\mathrm{a}}$ & $<\mathrm{DL}^{\mathrm{b}}$ & - & 0.33 & 0.01 & $<\mathrm{DL}$ & - \\
$\mathrm{Mg}$ & 2.16 & 0.01 & 6.14 & 0.02 & $<\mathrm{DL}$ & - \\
$\mathrm{Sn}$ & $<\mathrm{DL}$ & - & 1.47 & 0.07 & $<\mathrm{DL}$ & - \\
$\mathrm{K}$ & 10.84 & 0.66 & 34.59 & 0.10 & $<\mathrm{DL}$ & - \\
$\mathrm{Ca}$ & $<\mathrm{DL}$ & - & 2.22 & 2.48 & $<\mathrm{DL}$ & - \\
\hline
\end{tabular}

${ }^{\mathrm{a}} \mathrm{LOD}$ for $\mathrm{Pb}: 0,0057 \mu \mathrm{g} / \mathrm{g}, \mathrm{Al}$ and $\mathrm{Hg}: 0,0075 \mu \mathrm{g} / \mathrm{g}, \mathrm{Cu}: 0,0027 \mu \mathrm{g} / \mathrm{g}, \mathrm{Mn}$ : $0,005 \mu \mathrm{g} / \mathrm{g}, \mathrm{Fe}, \mathrm{Co}$, and Ni: 0,0012 $\mu \mathrm{g} / \mathrm{g}, \mathrm{Mg}: 0,0021 \mu \mathrm{g} / \mathrm{g}, \mathrm{Zn}: 0,0096 \mu \mathrm{g} / \mathrm{g}, \mathrm{Cr}$ and Cd: $0,0009 \mu \mathrm{g} / \mathrm{g}, \mathrm{Sn}: 0,003 \mu \mathrm{g} / \mathrm{g}, \mathrm{Na}: 0,3858 \mu \mathrm{g} / \mathrm{g}$, Ca: $0,0597 \mu \mathrm{g} / \mathrm{g}$, and K: $0,0162 \mu \mathrm{g} / \mathrm{g} ;{ }^{\mathrm{b}}<\mathrm{DL}$ : under detection limits; ${ }^{\mathrm{c}} \mathrm{SD}$ : Standard Deviation.

that location affects the mineral contents, especially $\mathrm{Cr}, \mathrm{Al}$, $\mathrm{Ca}, \mathrm{Cu}, \mathrm{Fe}, \mathrm{K}$, and $\mathrm{Na}$ of olive oils. Fe and $\mathrm{Mg}$ are known as increasing agents of lipid oxidation with their trace amounts [8]. Sahan (2010) determined Fe in green olives as $7.08 \mathrm{mg} / \mathrm{kg}$ and in black olives as $12.65 \mathrm{mg} / \mathrm{kg}$ [49] and FernandezHernandez et al. (2010) reported $\mathrm{Fe}$ as $0.513 \mathrm{mg} / \mathrm{kg}$ in olive oil samples [50]. In a study that was aimed at identifying geographical origin of the olive oil samples according to the mineral contents, Fe was found between $5.9 \mu \mathrm{g} / \mathrm{g}$ and $17.9 \mu \mathrm{g} / \mathrm{g}$ in Ayvalık olive cultivar collected from three different regions and found between $4.9 \mu \mathrm{g} / \mathrm{g}$ and $29.8 \mu \mathrm{g} / \mathrm{g}$ in Gemlik cultivar collected from five different regions [8]. Camin et al. (2010) reported $\mathrm{Mg}$ content between 0.016 and $0.017 \mu \mathrm{g} / \mathrm{g}$ for Calabria olive cultivar for Alto Crotonese, Bruzio, and Larnetia regions and 0.016 and $0.495 \mu \mathrm{g} / \mathrm{g}$ for Sicily olive cultivar for six different regions [10]. Arslan and Özcan (2011) reported $\mathrm{Mg}$ content between 1.7 and $7.1 \mu \mathrm{g} / \mathrm{g}$ for Ayvalık samples from three locations and between 2.3 and $5.4 \mu \mathrm{g} / \mathrm{g}$ for Gemlik samples from five locations [8]. $\mathrm{K}$ was reported between 0.08 and $0.32 \mu \mathrm{g} / \mathrm{g}$ for Calabria cultivar in three different locations and 0.12 and $9.94 \mu \mathrm{g} / \mathrm{g}$ for Sicily olive cultivar in six different regions [10]. The same researchers reported $\mathrm{Ca}$ content between 0.134 and $0.598 \mu \mathrm{g} / \mathrm{g}$ for a particular olive cultivar in six different locations. Arslan and Özcan (2011) reported higher amounts of Ca between 6.4 and $57.9 \mu \mathrm{g} / \mathrm{g}$ (Ayvalık cv.) and 6.0 and $38.3 \mu \mathrm{g} / \mathrm{g}$ (Gemlik cv.) in different growing regions. $\mathrm{K}$ was indicated in higher amounts than the other elements with the content of 219.21-281.8 $\mu \mathrm{g} / \mathrm{g}$ (Ayvalık $\mathrm{cv}$.) and 165.8-1575.8 $\mu \mathrm{g} / \mathrm{g}$ (Gemlik cv.) in different growing regions [8]. If we compare our findings with literature, Fe, $\mathrm{K}$, and $\mathrm{Ca}$ contents of the samples were both higher and lower according to other results and $\mathrm{Mg}$ was higher partially.

\section{Conclusions}

In conclusion, the data obtained in this research show that Edincik Su olive cultivar has high antioxidant capacity including high amounts of total phenolic content and free radical scavenging activity. There was no linear correlation between TPC and FRSA while Edincik sample which is the origin of Edincik Su sample had the highest TPC and Izmir sample had the highest FRSA. The highest antimicrobial activities were determined against Clostridium perfringens ATCC 13124 and Campylobacter jejuni ATCC 33291. Finally, Edincik Su olive oils had high antioxidant activity and had antimicrobial effect against a wide range of microorganisms. This cultivar has limited mineral contents. Thus, it can be said that location has a significant effect on the antioxidant activity, phenolic compounds, antimicrobial activities of the phenolic extracts, and mineral contents of olive oils. The results of the study may present new and useful information for establishment of new plantations and for the international literature for this unique olive cultivar.

\section{Competing Interests}

The author certifies that there are no actual or potential competing interests in relation to this paper.

\section{References}

[1] G. Cioffi, M. S. Pesca, P. De Caprariis, A. Braca, L. Severino, and N. De Tommasi, "Phenolic compounds in olive oil and olive pomace from Cilento (Campania, Italy) and their antioxidant activity," Food Chemistry, vol. 121, no. 1, pp. 105-111, 2010.

[2] A. E. Binkoski, P. M. Kris-Etherton, T. A. Wilson, M. L. Mountain, and R. J. Nicolosi, "Balance of unsaturated fatty acids is important to a cholesterol-lowering diet: comparison of midoleic sunflower oil and olive oil on cardiovascular disease risk factors," Journal of the American Dietetic Association, vol. 105, no. 7, pp. 1080-1086, 2005.

[3] M. Douzane, A. Tamendjari, A. K. Abdi, M.-S. Daas, F. Mehdid, and M. M. Bellal, "Phenolic compounds in mono-cultivar extra virgin olive oils from Algeria," Grasas y Aceites, vol. 64, no. 3, pp. 285-294, 2013.

[4] H. Karaosmanoglu, F. Soyer, B. Ozen, and F. Tokatli, "Antimicrobial and antioxidant activities of Turkish extra virgin olive oils," Journal of Agricultural and Food Chemistry, vol. 58, no. 14, pp. 8238-8245, 2010.

[5] S. Cicerale, L. J. Lucas, and R. S. J. Keast, "Antimicrobial, antioxidant and anti-inflammatory phenolic activities in extra virgin olive oil," Current Opinion in Biotechnology, vol. 23, no. 2, pp. 129-135, 2012.

[6] E. Medina, C. Romero, M. Brenes, and A. De Castro, "Antimicrobial activity of olive oil, vinegar, and various beverages against foodborne pathogens," Journal of Food Protection, vol. 70, no. 5, pp. 1194-1199, 2007.

[7] G. Yildiz and V. Uylaser, "Dogal bir antimikrobiyel: oleuropein," Uludă̆ Üniversitesi Ziraat Fakültesi Dergisi, vol. 25, no. 1, pp. 131-142, 2011.

[8] D. Arslan and M. M. Özcan, "Güney Anadolu'dan Farklı Çeşitlere Ait Zeytin Yağlarının Mineral Madde Iç̧eriği Üzerine Lokasyon ve Hasat Döneminin Etkisi," Uludă̆ Üniversitesi Ziraat Fakültesi Dergisi, vol. 25, no. 1, pp. 11-26, 2011.

[9] S. B. Yaşar, K. Baran, and M. Alkan, "Metal determinations in olive oil," in Olive Oil-Constituents, Quality, Health Properties and Bioconversions, B. Dimitrios, Ed., chapter 5, pp. 89-108, InTech, Rijeka, Croatia, 2012.

[10] F. Camin, R. Larcher, M. Perini et al., "Characterisation of authentic Italian extra-virgin olive oils by stable isotope ratios of $\mathrm{C}, \mathrm{O}$ and $\mathrm{H}$ and mineral composition," Food Chemistry, vol. 118, no. 4, pp. 901-909, 2010.

[11] M. Andjelkovic, S. Acun, V. Van Hoed, R. Verhé, and J. Van Camp, "Chemical composition of Turkish olive oil-Ayvalik," 
Journal of the American Oil Chemists' Society, vol. 86, no. 2, pp. 135-140, 2009.

[12] IOOC, "World olive oil figures," 2016, http://www.internationaloliveoil.org/estaticos/view/131-world-olive-oil-figures.

[13] TUIK, “Zeytin üretimi," 2016, 1988-2014, http://www.tuik.gov .tr/PreTablo.do?alt_id=1001.

[14] UZZK, “Türkiye zeytin ve zeytinyağ1 rekolte tahmini,” 2012, http://uzzk.org.

[15] N. Özilbey, Zeytin Çeşitlerimiz, Sidas Medya Ltd. Şti, Izmir, Turkey, 2011.

[16] F. Longobardi, A. Ventrella, G. Casiello et al., "Characterisation of the geographical origin of Western Greek virgin olive oils based on instrumental and multivariate statistical analysis," Food Chemistry, vol. 133, no. 1, pp. 169-175, 2012.

[17] M. Uceda and M. Hermoso, "La calidad del aceite de oliva," in El Cultivo del Olivo, D. Barranco, R. Fernandez-Escobar, and L. Rallo, Eds., pp. 547-572, Junta de Andalucia Ediciones MundiPrensa, Madrid, Spain, 1998.

[18] V. L. Singleton and J. R. Rossi, "Colorimetry of total phenolics with phosphomolibdic-phosphothungstic acid," American Journal of Enology and Viticulture, vol. 16, pp. 144-158, 1965.

[19] H. J. D. Dorman, A. Peltoketo, R. Hiltunen, and M. J. Tikkanen, "Characterisation of the antioxidant properties of de-odourised aqueous extracts from selected Lamiaceae herbs," Food Chemistry, vol. 83, no. 2, pp. 255-262, 2003.

[20] F. Caponio, V. Alloggio, and T. Gomes, "Phenolic compounds of virgin olive oil: influence of paste preparation techniques," Food Chemistry, vol. 64, no. 2, pp. 203-209, 1999.

[21] H. K. Obied, D. R. Bedgood Jr., P. D. Prenzler, and K. Robards, "Bioscreening of Australian olive mill waste extracts: biophenol content, antioxidant, antimicrobial and molluscicidal activities," Food and Chemical Toxicology, vol. 45, no. 7, pp. 1238-1248, 2007.

[22] S. B. Yaşar and Ş. Güçer, "Fractionation analysis of magnesium in olive products by atomic absorption spectrometry," Analytica Chimica Acta, vol. 505, no. 1, pp. 43-49, 2004.

[23] S. Dabbou, I. Rjiba, A. Nakbi, N. Gazzah, M. Issaoui, and M. Hammami, "Compositional quality of virgin olive oils from cultivars introduced in Tunisian arid zones in comparison to Chemlali cultivars," Scientia Horticulturae, vol. 124, no. 1, pp. 122-127, 2010.

[24] A. Dag, Z. Kerem, N. Yogev, I. Zipori, S. Lavee, and E. BenDavid, "Influence of time of harvest and maturity index on olive oil yield and quality," Scientia Horticulturae, vol. 127, no. 3, pp. 358-366, 2011.

[25] S. A. Vekiari, V. Oreopoulou, Y. Kourkoutas et al., "Characterization and seasonal variation of the quality of virgin olive oil of the Throumbolia and Koroneiki varieties from Southern Greece," Grasas y Aceites, vol. 61, no. 3, pp. 221-231, 2010.

[26] W. Zarrouk, F. M. Haddada, B. Baccouri et al., "Characterization of virgin olive oil from Southern Tunisia," European Journal of Lipid Science and Technology, vol. 110, no. 1, pp. 81-88, 2008.

[27] M. Issaoui, S. Dabbou, A. Echbili et al., "Biochemical characterisation of some Tunisian virgin olive oils obtained from different cultivars growing in Sfax National Collection," Journal of Food, Agriculture and Environment, vol. 5, no. 1, pp. 17-21, 2007.

[28] H. Uğurlu Aşık and G. Ozkan, "Physical, chemical and antioxidant properties of olive oil extracted from memecik cultivar," Akademik Gıda, vol. 9, no. 2, pp. 13-18, 2011.

[29] H. İlyasoğlu and B. Özçelik, "Memecik zeytinyağlarının biyokimyasal karakterizasyonu," Gıda, vol. 36, no. 1, pp. 33-41, 2011.
[30] K. Tanılgan, M. M. Özcan, and A. Ünver, "Physical and chemical characteristics of five Turkish olive (Olea europea L.) varieties and their oils," Grasas y Aceites, vol. 58, no. 2, pp. 142-147, 2007.

[31] G. Del Monaco, A. Officioso, S. D’Angelo et al., "Characterization of extra virgin olive oils produced with typical Italian varieties by their phenolic profile," Food Chemistry, vol. 184, pp. 220-228, 2015.

[32] M. Issaoui, G. Flamini, F. Brahmi et al., "Effect of the growing area conditions on differentiation between Chemlali and Chétoui olive oils," Food Chemistry, vol. 119, no. 1, pp. 220-225, 2010.

[33] H. Kelebek, S. Kesen, Ç. Sabbağ, and S. Selli, "Gemlik zeytin çeşidinden elde edilen natürel zeytinyağında fenol bileşiklerinin ve antioksidan kapasitenin belirlenmesi," Gıda, vol. 37, no. 3, pp. 133-140, 2012.

[34] M. Kiralan, A. Bayrak, and M. T. Özkaya, "Oxidation stability of virgin olive oils from some important cultivars in east mediterranean area in turkey," Journal of the American Oil Chemists' Society, vol. 86, no. 3, pp. 247-252, 2009.

[35] B. Bayram, T. Esatbeyoglu, N. Schulze, B. Ozcelik, J. Frank, and G. Rimbach, "Comprehensive analysis of polyphenols in 55 Extra virgin olive oils by HPLC-ECD and their correlation with antioxidant activities," Plant Foods for Human Nutrition, vol. 67, no. 4, pp. 326-336, 2012.

[36] M. Öğütçü and E. Yılmaz, "Comparison of the virgin olive oils produced in different regions of Turkey," Journal of Sensory Studies, vol. 24, no. 3, pp. 332-353, 2009.

[37] F. Brahmi, B. Mechri, M. Dhibi, and M. Hammami, "Variations in phenolic compounds and antiradical scavenging activity of Olea europaea leaves and fruits extracts collected in two different seasons," Industrial Crops and Products, vol. 49, pp. 256264, 2013.

[38] G. Yildiz and V. Uylaşer, "Profile and total content of phenolics and antioxidant activity of commercial table olives from Turkey," Quality Assurance and Safety of Crops and Foods, vol. 7, no. 5, pp. 635-642, 2015.

[39] A. Dagdelen, G. Tümen, M. M. Özcan, and E. Dündar, "Phenolics profiles of olive fruits (Olea europaea L.) and oils from Ayvalik, Domat and Gemlik varieties at different ripening stages," Food Chemistry, vol. 136, no. 1, pp. 41-45, 2013.

[40] M. J. Lerma-García, C. Lantano, E. Chiavaro, L. Cerretani, J. M. Herrero-Martínez, and E. F. Simó-Alfonso, "Classification of extra virgin olive oils according to their geographical origin using phenolic compound profiles obtained by capillary electrochromatography," Food Research International, vol. 42, no. 10, pp. 1446-1452, 2009.

[41] D. Alkan, F. Tokatli, and B. Ozen, "Phenolic characterization and geographical classification of commercial extra virgin olive oils produced in Turkey," Journal of the American Oil Chemists' Society, vol. 89, no. 2, pp. 261-268, 2012.

[42] B. Bayram, T. Esatbeyoglu, N. Schulze, B. Ozcelik, J. Frank, and G. Rimbach, "Comprehensive analysis of polyphenols in 55 extra virgin olive oils by HPLC-ECD and their correlation with antioxidant activities," Plant Foods for Human Nutrition, vol. 67, no. 4, pp. 326-336, 2012.

[43] D. Ocakoglu, F. Tokatli, B. Ozen, and F. Korel, "Distribution of simple phenols, phenolic acids and flavonoids in Turkish monovarietal extra virgin olive oils for two harvest years," Food Chemistry, vol. 113, no. 2, pp. 401-410, 2009.

[44] H. Ilyasoglu, B. Ozcelik, V. Van Hoed, and R. Verhe, "Characterization of aegean olive oils by their minor compounds," Journal 
of the American Oil Chemists' Society, vol. 87, no. 6, pp. 627-636, 2010.

[45] M. Korukluoglu, Y. Sahan, A. Yigit, E. T. Ozer, and S. Gücer, "Antibacterial activity and chemical constitutions of Olea europaea 1. leaf extracts," Journal of Food Processing and Preservation, vol. 34, no. 3, pp. 383-396, 2010.

[46] O.-H. Lee and B.-Y. Lee, "Antioxidant and antimicrobial activities of individual and combined phenolics in Olea europaea leaf extract," Bioresource Technology, vol. 101, no. 10, pp. 3751-3754, 2010.

[47] C. Benincasa, M. Gharsallaoui, E. Perri et al., "Quality and trace element profile of tunisian olive oils obtained from plants irrigated with treated wastewater," The Scientific World Journal, vol. 2012, Article ID 535781, 11 pages, 2012.

[48] I. J. Cindric, M. Zeiner, and I. Steffan, "Trace elemental characterization of edible oils by ICP-AES and GFAAS," Microchemical Journal, vol. 85, no. 1, pp. 136-139, 2007.

[49] Y. Sahan, "Some metals in table olives," in Olives and Olive Oil in Health and Disease Prevention, V. R. Preedy and R. R. Watson, Eds., chapter 32, pp. 299-306, 2010.

[50] A. Fernandez-Hernandez, R. Mateos, J. A. Garcia-Mesa, G. Beltran, and R. Fernandez-Escobar, "Determination of mineral elements in fresh olive fruits by flame atomic spectrometry," Spanish Journal of Agricultural Research, vol. 8, no. 4, pp. 11831190, 2010. 

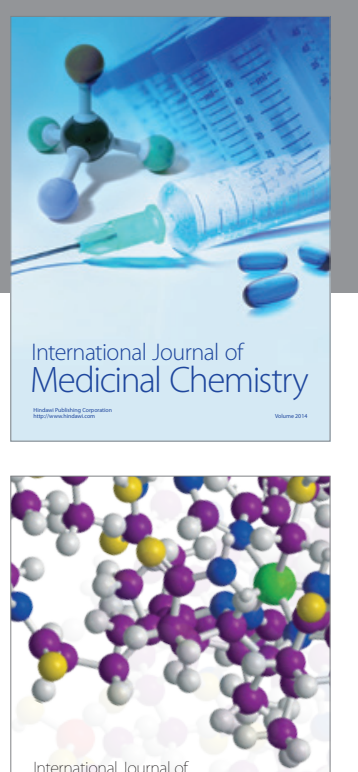

Carbohydrate Chemistry

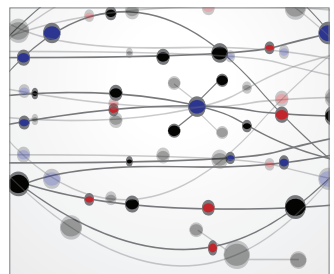

The Scientific World Journal
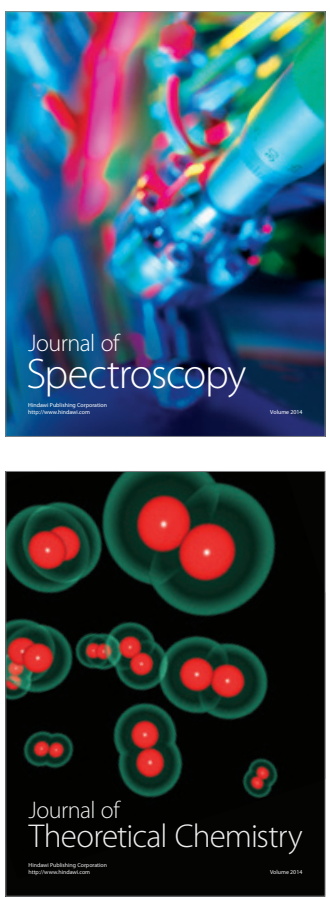
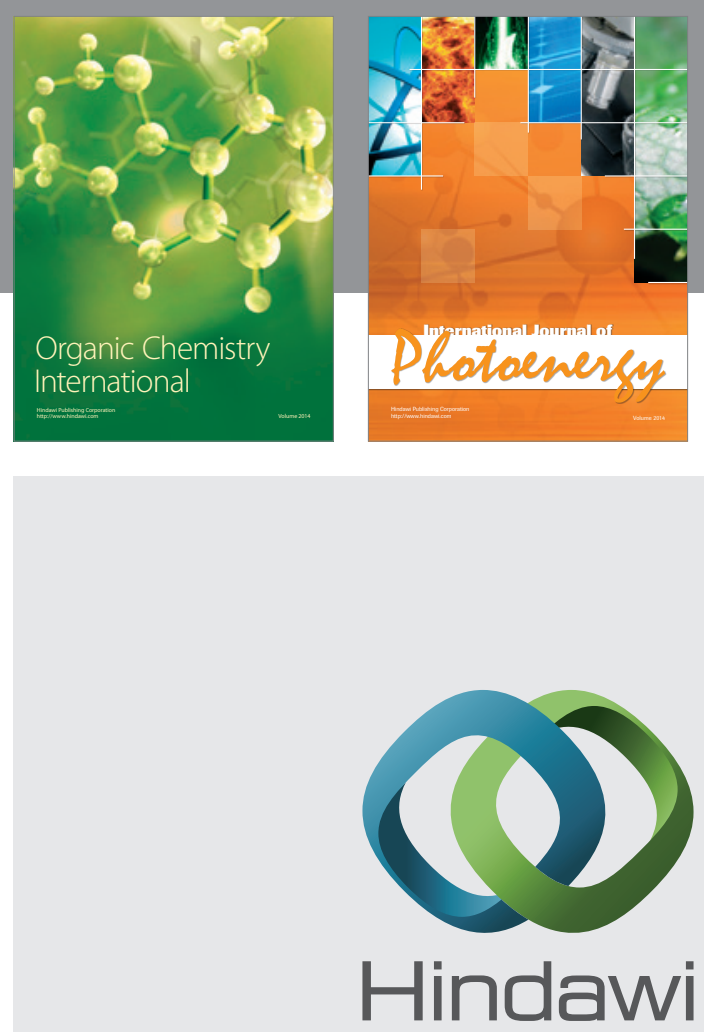

Submit your manuscripts at

http://www.hindawi.com

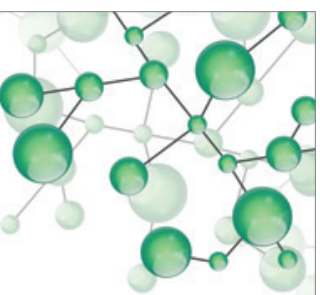

International Journal of

Inorganic Chemistry

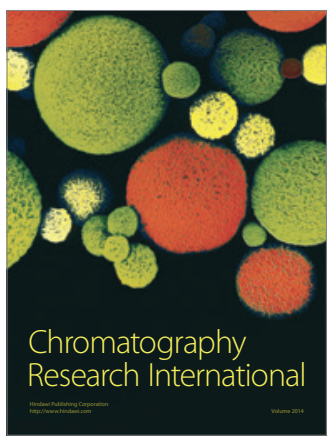

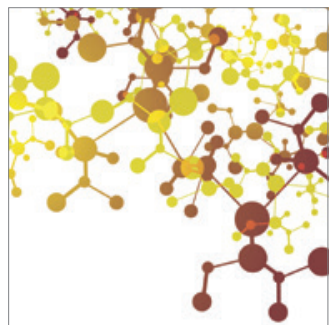

Applied Chemistry
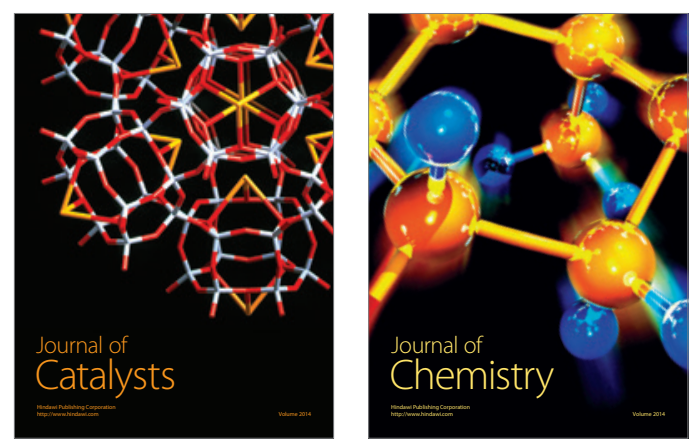
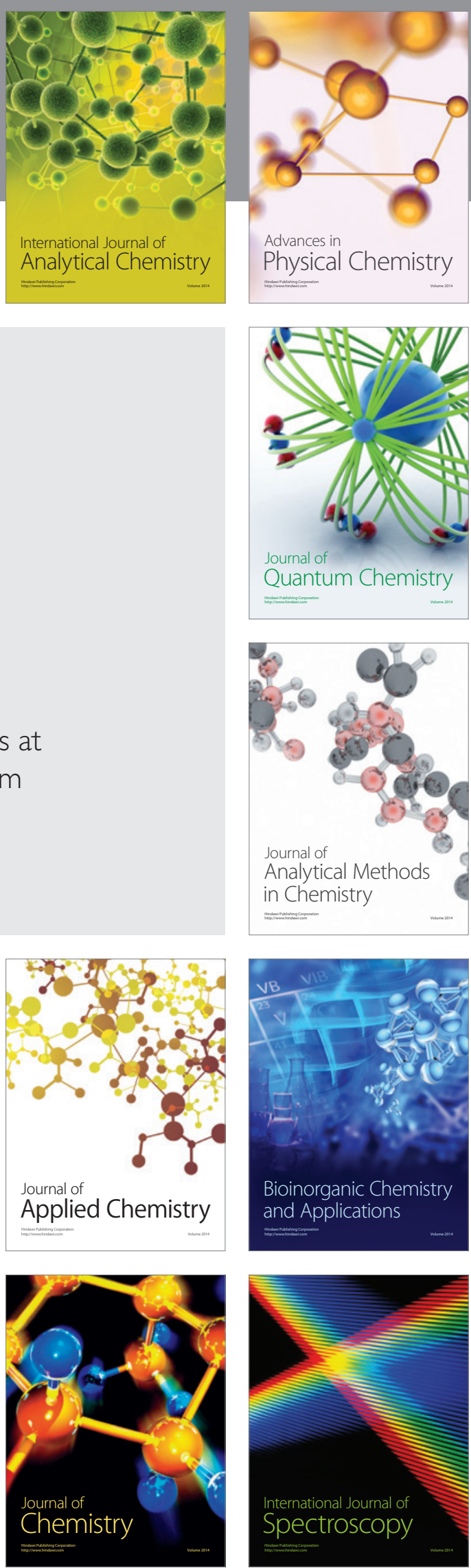